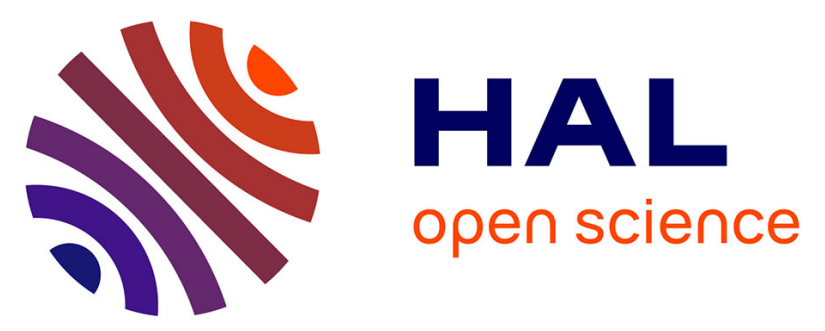

\title{
The effect of a GnRH agonist on follicular dynamics and response to FSH stimulation in prepubertal calves1
}

\author{
Jacques J. Dufour, Pascal Mermillod, Jean-Claude Mariana, Robert F. \\ Romain
}

\section{- To cite this version: \\ Jacques J. Dufour, Pascal Mermillod, Jean-Claude Mariana, Robert F. Romain. The effect of a GnRH agonist on follicular dynamics and response to FSH stimulation in prepubertal calves1. Reproduction Nutrition Development, 1999, 39 (1), pp.133-144. hal-00900288}

\section{HAL Id: hal-00900288 \\ https://hal.science/hal-00900288}

Submitted on 1 Jan 1999

HAL is a multi-disciplinary open access archive for the deposit and dissemination of scientific research documents, whether they are published or not. The documents may come from teaching and research institutions in France or abroad, or from public or private research centers.
L'archive ouverte pluridisciplinaire HAL, est destinée au dépôt et à la diffusion de documents scientifiques de niveau recherche, publiés ou non, émanant des établissements d'enseignement et de recherche français ou étrangers, des laboratoires publics ou privés. 


\title{
The effect of a GnRH agonist on follicular dynamics and response to FSH stimulation in prepubertal calves ${ }^{1}$
}

\author{
Jacques J. Dufour ${ }^{\mathrm{a} *}$, Pascal Mermillod ${ }^{\mathrm{b}}$, Jean-Claude Mariana ${ }^{\mathrm{b}}$, \\ Robert F. Romain ${ }^{\mathrm{c}}$ \\ a Département des sciences animales, FSAA, Université Laval, \\ Sainte-Foy, Quebec, PQ G1K 7P4, Canada \\ b Physiologie de la reproduction des mammifères domestiques, Inra, 37380 Nouzilly, France \\ ${ }^{c}$ Centre de recherche en économie agroalimentaire, FSAA, Université Laval, \\ Sainte-Foy, Quebec, PQ G1K 7P4, Canada
}

(Received 27 January 1998; accepted 2 December 1998)

\begin{abstract}
Endocrine control of follicular growth was determined by observing the left ovary of prepubertal calves previously treated with a potent GnRH agonist for 13 days. The ovarian response to hormonal stimulation was determined using the right ovaries of the same animals. Three-month-old crossbred calves were assigned to one of the two following treatment groups: 1) saline control for 13 days, with purified porcine FSH for the last 3 days $(n=5)$; and 2) GnRHa for 13 days, with purified porcine FSH for the final 3 days $(n=5)$. The left ovaries were removed from all calves after - 10 days, and the right ovaries were removed at the end of treatment. Plasma concentrations of FSH, LH and oestradiol-17 $\beta$ were followed up during the GnRHa and pFSH treatments. The maximum macroscopic diameter of the $\mathrm{F} 1$ follicle, as determined by daily ultrasonography, did not differ between GnRHa-treated calves (from 6.6 to $10.4 \mathrm{~mm}$ ) and the saline control calves (from 6.7 to $10.3 \mathrm{~mm}$ ). Histological analysis of the ovaries showed that the number of follicles $>0.40 \mathrm{~mm}$ in diameter varied greatly for calves of the two groups (from 11 to 220 at 10 days). GnRHa significantly increased the mean number of follicles (total and nonatretic) of size class $>5.4 \mathrm{~mm}$ as compared to saline control calves $(P<0.05)$. The FSH treatment significantly increased the mean number of follicles 3.00-5.4 and $>5.4 \mathrm{~mm}$ in diameter $(P<0.05)$, with no change in the number of follicles smaller than $3.00 \mathrm{~mm}$. The rate of atresia of large follicles $(3.01-5.40 \mathrm{~mm})$ was significantly reduced by purified porcine FSH treatment in both groups $(P<0.05)$. In no case did the GnRHa induce ovulation or luteinization of follicles. The LH and FSH concentrations increased transiently after GnRHa treatment on the first day, but afterwards, both hormones increased to only one sixth of what was observed after the initial GnRHa injection treatment. This increase in LH and FSH was observed $1 \mathrm{~h}$ after GnRHa treatment on each consecutive day of the experiment and were significantly different in the control group $(0 \mathrm{~h}$ versus $1 \mathrm{~h}$ versus $2 \mathrm{~h} \times$ saline control versus $\mathrm{GnRH}$ agonists groups;
\end{abstract}

\footnotetext{
${ }^{1}$ Research supported in part by CORPAQ and FCAR, Quebec, and Inra, France

* Correspondence and reprints

E-mail: jacques.dufour@crbr.ulaval.ca
} 
$P<0.01$ ). During the superovulatory treatment, FSH concentrations peaked at around $0.70 \mathrm{ng} \cdot \mathrm{mL}^{-1}$ in both saline- and GnRHa-treated groups on the first day but on the last day of surovulatory treatment, FSH concentrations were higher in GnRHa agonist-treated calves than in the control calves (day 11 versus day 12 versus day $13 \times$ saline control versus $\mathrm{GnRH}$ agonist treatment groups; $P<0.01$ ). $\mathrm{LH}$ profiles were unchanged by surovulatory treatment. Concentrations of oestradiol-17 $\beta$ increased significantly over the three days $(P<0.001)$ of the superovulatory treatments in both groups $(P<0.01)$. These results indicate that $\mathrm{GnRH}$ agonist treatment allows recruited antral follicles to pursue their growth during the early selection process via sustained FSH and LH secretion allowing more than a single large follicle to maintain their growth without going to atresia. (C) Inra/Elsevier, Paris.

\section{folliculogenesis / GnRH / FSH /'superovulation / calves}

Résumé - Effet d'un agoniste du GnRH sur la dynamique folliculaire et la réponse à la stimulation par la FSH chez le veau prépubère. En vue d'étudier le contrôle endocrinien de la croissance folliculaire avant la puberté, l'ovaire gauche de jeunes veaux a été observé après un traitement de $13 \mathrm{j}$ avec un agoniste du $\mathrm{GnRH}$ (GnRHa). La réponse à un traitement de stimulation a ensuite été étudiée sur l'ovaire droit des mêmes animaux. Des veaux de trois mois ont été répartis parmi les deux traitements suivants : 1) injection de solution physiologique pendant $13 \mathrm{j}$, accompagnée de FSH porcine purifié pendant les trois derniers jours $(n=5)$; et 2$) \mathrm{GnRHa}$ pendant $13 \mathrm{j}$ FSH porcine purifiée pendant les trois derniers jours $(n=5)$. L'ovaire gauche a été prélevé chirurgicalement après $10 \mathrm{j}$ dans les deux groupes et l'ovaire droit a été prélevé après abattage des veaux à la fin du traitement. Des prélèvements sanguins étaient effectués tout au long de l'étude dans le but de suivre les changements de sécrétion de FSH, LH et œstradiol-17 $\beta$ durant les traitements de GnRHa et de pFSH. Le diamètre du plus gros follicule, suivi quotidiennement par échographie, passe par un maximum qui ne diffère pas entre les deux groupes (de 6,6 à 10,4 mm pour le groupe GnRHa et de 6,7 à 10,3 mm pour le groupe témoin ). L'analyse histologique a montré un nombre très variable de follicules de plus de $0,4 \mathrm{~mm}$ dans les deux groupes (de 11 à 220 follicules à $10 \mathrm{j}$ ). Le traitement de GnRHa augmente de façon statistique le nombre moyen de follicules (total et nonatrétique) de taille de plus de $5,4 \mathrm{~mm}$ sans altérer la population de follicules de 3 à $5,4 \mathrm{~mm}$ de diamètre $(p<0,05)$. Le traitement de FSH augmente significativement chez les deux groupes le nombre de follicules de tailles $3,00-5,4$ et de plus de $5,4 \mathrm{~mm}$ sans altérer la population de follicules de taille plus petites $(p<0,05)$. Le taux d'atrésie des follicules de taille 3,01 à $5,4 \mathrm{~mm}$ est réduit significativement par le traitement de FSH chez les deux groupes de veaux $(p<0,05)$. En aucun cas le GnRHa n'a provoqué l'ovulation ou la lutéinisation des gros follicules. Les concentrations plasmatiques de LH et FSH augmentent transitoirement après la première injection de GnRHa. Suite aux injections suivantes, l'augmentation du niveau de LH et de FSH sont réduites mais significativement différentes de celles observées chez le groupe témoin et ce, des jours 2 à $10(0 \mathrm{~h}$ vs $1 \mathrm{~h}$ vs $2 \mathrm{~h} \times$ saline control vs GnRHa groupes; $p<0,01)$. Pendant le traitement de stimulation, le niveau de FSH est comparable pour les deux premiers jours mais pas pour le dernier jour où il est plus élevé pour le groupe GnRHa à $1 \mathrm{~h}$ et $2 \mathrm{~h}(\mathrm{j} 11$ vs j 12 vs jour $13 \times$ saline control vs GnRHa groupes ; $p<0,01$ ). Le niveau de LH est inchangé pendant le traitement de stimulation. Les concentrations d'œstradiol augmentaient de façon significative avec les jours de superovulation chez les deux groupes $(p<0,001)$. Ces résultats indiquent que la GnRH permet aux follicules recrutés de poursuivre leur croissance au cours du processus de sélection via la sécrétion continue de LH et FSH induite, permettant ainsi à plus d'un seul follicule de grande taille de maintenir leur croissance sans tomber en atrésie. () Inra/Elsevier, Paris.

\section{folliculogenèse / GnRH / FSH / superovulation / veaux}




\section{INTRODUCTION}

Recruitment and selection of ovulatory follicles are two processes that are known to regulate growth and differentiation and to control ovulation rates, with selection being achieved by atresia of the recruited follicles. In females with multiple ovulations, high ovulation rates can be achieved through an increase in the number of recruited follicles with a fixed selection rate or by a decrease in the selection rate along with no change in the rate of follicle recruitment $[9$, 14].

Treatment with FSH can increase the number of dominant follicles by stimulating recruitment and protecting follicles from the selection process, thus allowing multiple ovulations $[1,18]$. The FSH level appears to be important during early selection [20] while the FSH/LH ratio influences the rate of atresia and ovulation rate [22]. However, some ovarian factors have been shown to influence the superovulatory treatment, and may explain why females treated alike differ so widely in their response.

Among ovarian factors known to influence the superstimulatory effects of FSH in cattle is the follicular status which is highly variable among individuals. Fewer ovulations are observed when superstimulatory treatments are initiated in the presence of a dominant follicle [23]. Conversely, higher ovulation rates are reported when large numbers of small follicles are present at the time of superstimulatory treatments [24].

Dominant follicles have been shown to have limited growth in postpubertal heifers treated with GnRH agonists $[10,15,16]$. In addition, the duration of GnRHa treatment [10] has been shown to increase the proportion of medium size follicles, indicating that the growth of medium follicles can be facilitated by blocking the inhibitory effect of dominant follicles on follicular development, or by a direct stimulatory effect on the follicle reserve pool formation, or both.
The ovarian physiology of prepubertal heifers appears to be different from postpubertal heifers in that all essential factors for superovulatory treatments are positive. Growth of the largest follicle is not limited by agonist treatments [12] and the pool of growing follicles, known to modify ovulatory response in postpubertal heifers, is greater before puberty than after in cattle [11]. The large variation in the number of medium size follicles among postpubertal heifers (from 2 to 87 follicles) [21] has not been observed before puberty by macroscopic studies [19].

The purpose of the present experiment was to determine, in prepubertal heifers previously treated with a GnRH agonist, how the ovarian response, recruitment (number of follicles) and selection (rate of atresia) to superovulatory treatments is affected by the population of follicles present at treatment by comparing the ovarian follicular population in the same heifers before and after injection of highly purified FSH.

\section{MATERIALS AND METHODS}

\subsection{Experimental groups}

Ten 3-month-old crossbred calves were randomly assigned to one of two experimental groups: 1) saline for 13 days, with purified porcine FSH during the last 3 days $(n=5)$ and 2) GnRHa for 13 days, with purified porcine FSH for the last 3 days $(n=5)$. Following treatment with GnRHa (saline for control) for 10 days, the left ovary was removed by hemicastration. The right ovary was removed at the end of the experiment to determine the effect of a superovulatory hormonal treatment imposed for the last 3 days. Ovaries were studied histologically for population of follicles.

Two millilitres of a physiological saline solution containing $24 \mu \mathrm{g} \cdot \mathrm{mL}^{-1}$ of GnRHa (Leuproréline, Enantone, gift from Takeda, Puteaux, France) were injected subcutaneously twice daily $(0800$ and 1700 hours). The GnRHa dosage and frequency of administration were the same as that used for postpubertal heifers [10] and were adequate to induce a preovulatory surge-like $\mathrm{LH}$ secretion (unpublished data). 
Purified porcine FSH (Primufol, Rhône Mérieux, France) containing $<1 \mu \mathrm{g} \mathrm{LH} / 150 \mu \mathrm{g}$ FSH was injected intramuscularly twice daily (0800 and 1700 hours) in decreasing doses over 3 days (total of $16 \mathrm{mg}$ of purified porcine $\mathrm{pFSH}$ ).

\subsection{Hormone analyses}

The regimen of blood sampling was chosen based on the results of a previous study (unpublished data) where LH was seen to be at its maximum concentration $2 \mathrm{~h}$ after the morning GnRHa injection, before reaching basal levels 4 and $5 \mathrm{~h}$ later. Jugular blood samples were collected three times daily (0800, 0900 and 1000 hours) throughout the experiment. The first sampling was performed immediately before GnRHa and FSH injections. Plasma concentrations of oestradiol-17 $\beta$ [26] were determined by radioimmunoassay in a single assay. The sensitivity of the oestradiol- $17 \beta$ assay was $0.6 \mathrm{pg} \cdot \mathrm{mL}^{-1}$ and the intra-assay coefficient of variation was $6 \%$. Serum concentrations of FSH and LH were determined by double antibody RIA [6].

Reagents for the LH assay included an ovineLH-antiserum (Inra, Nouzilly, MP Dubois) as the first antibody and oLH-1086 (Inra, Nouzilly, Y Combarnous) as the tracer and standard. The sensitivity of the $\mathrm{LH}$ assay was $0.01 \mathrm{ng} \cdot \mathrm{mL}^{-1}$, and the intra- and inter-assay coefficients of variation were 7.54 and $11.57 \%$, respectively.

Reagents for the FSH assay included bovine FSH as the iodinated tracer (USDA-bFSH-1-2), bovine FSH (USDA-bFSH-1-2) as the cold standard, and rabbit anti-ovine FSH (NIDDK-antioFSH-1) as the first antibody. The sensitivity of the assay was $0.01 \mathrm{ng} \cdot \mathrm{mL}^{-1}$, and the intra- and inter-assay coefficients of variation were 5.3 and $10.6 \%$, respectively. For both LH and FSH assays, sheep anti-rabbit gammaglobulin was used as a precipitating second antibody.

Concentrations of LH and FSH were determined for each of the three blood samples collected per day, and that for oestradiol was determined for pooled daily samples for each calf. For the LH assay, a value of $0.01 \mathrm{ng} \cdot \mathrm{mL}^{-1}$ was attributed by the software program (four parameter logistic; Iso-Data software, ICN Biomedical Inc., Micromedic Systems) to samples whose values were below the levels of sensitivity of the assay.

\subsection{Ovarian analyses}

Ovarian surfaces in all calves were photographed daily using a real-time linear scanning ultrasound diagnostic system (Combison 310A: Kretz Technik) equipped with a $7.5 \mathrm{MHz}$ rectal transducer. Follicles larger than $5.0 \mathrm{~mm}$ were counted and their diameters were measured from the photographs.

Within 5 min of collection, ovaries were perfused with Bouin-Hollande fixative through the utero-ovarian artery, then immersed in fixative for 15 days. After fixation, ovaries were embedded in paraffin wax and serially sectioned at a thickness of $7 \mu \mathrm{m}$. Every fifth section was mounted, stained with hematoxylin and observed. Antral follicles were counted, measured and classified as atretic or nonatretic. A follicle was classed as atretic when five or more pycnotic bodies were observed bordering or within the granulosa cells of the section studied. All measurements were made on the section where the oocyte was found except for the largest follicles for which measurements were recorded from the largest section limited by the basement membrane.

The area of each follicle was determined by using an electronic planimeter to trace around the basement membrane through a drawing tube fixed to the microscope. The diameter of the follicle $(\mathrm{mm})$ was calculated from the area $\left(\mu \mathrm{m}^{2}\right)$ by assuming that it was circular. The number of follicles $>0.40 \mathrm{~mm}$ was determined and these were classified as either atretic or nonatretic according to the number of pycnotic bodies in the granulosa cells. Follicles were grouped into three size classes as follows: class $1,0.40-3.00 \mathrm{~mm}$; class $2,3.01-5.40 \mathrm{~mm}$, class 3 , greater than 5.40 .

\subsection{Statistical analysis}

\subsubsection{Endocrine data}

Data for FSH, LH and oestradiol were analysed by ANOVA procedures using the General Linear Models (GLM) of SAS/STAT [25]. Data analyses for hormone concentrations over time were undertaken by repeated measures [5]. The variation in hormonal concentration was determined within three different physiological stages induced specifically by treatments. The first physiological stage occurred immediately following the morning injection of GnRH agonist on day 1. The second physiological stage is known as the castration-like phenomenon where hormonal concentrations are low (days 2-10). The third 
physiological stage was associated with the FSH superovulatory treatment (days 11-13).

\subsubsection{Follicular data}

The effect of treatment was tested statistically by an ANOVA using a split-plot model, the whole unit being the calves within treatment. The effect of FSH was tested within treatments, the calves within treatment being the sub-unit. The follicular size was not included as a factor because of lack of homogeneity of variance among small and large follicles. Data for follicles were $\log 10$ transformed to achieve homogeneity of variances.

\section{RESULTS}

\subsection{FSH and LH hormone concentrations}

FSH concentrations in saline-treated calves did not vary much prior to superovulatory treatments (from 0.1 and $0.2 \mathrm{ng} \cdot \mathrm{mL}^{-1}$; figure 1A). However, in GnRHa-treated calves FSH concentrations increased significantly at each of the first two physiological stages. On day 1 of GnRHa treatment (the first physiological stage), FSH concentrations increased significantly to reach between 0.6 and $2.0 \mathrm{ng} \cdot \mathrm{mL}^{-1}$ at $2 \mathrm{~h}$ post-injection (time $\times$ treatment interaction; $P<0.001$; figure $1 A, B$ ). Between days 2 and 10 of GnRHa treatment (second physiological stage; figure $1 B$ ), FSH levels were always higher following treatment at 1 and $2 \mathrm{~h}$ when compared to saline-treated calves (time $\times$ treatment interaction; $P<0.001$; figure $1 A, B ; P<0.01$ ). Superovulatory treatment (third physiological stage) of GnRHatreated calves resulted in FSH concentrations reaching a maximum $2 \mathrm{~h}$ after injections on each of the 3 days (figure $1 A, B$ ). FSH concentrations at 1 and $2 \mathrm{~h}$ following superovulation were similar and increased significantly in both groups but decreased with days of treatments (day 11 versus day 12 versus day 13 of superovulation; $P<0.001$ ). The FSH concentration measured on the third day of superovulation was higher at
1 and $2 \mathrm{~h}$ in GnRHa agonist-treated calves than in saline-treated control calves (time $\times$ treatment interaction; $P<0.001$ ).

LH concentrations in saline control calves remained at basal levels in two calves throughout the study with no increase observed at any of the sampling periods $\left(0.01 \pm 0.00 \mathrm{ng} \cdot \mathrm{mL}^{-1}\right)$. In the three remaining calves, 3, 4 and 7 LH spikes were observed over the time course of the study (days 1 , 6 and 11; days 4, 5, 9 and 11 ; days 2, 3, 4, 9, 10,11 and 12). Except for one spike of greater than $12 \mathrm{ng} \cdot \mathrm{mL}^{-1}$, most were between 2 and $4 \mathrm{ng} \cdot \mathrm{mL}^{-1}$. When all saline-treated calves were analysed as a group (figure $1 \mathrm{C}$ ), $\mathrm{LH}$ concentrations at 0,1 and $2 \mathrm{~h}$ after treatment did not differ statistically throughout the study $(P>0.10)$.

The $\mathrm{LH}$ profiles were very similar among calves treated with GnRHa for 13 days (figure $1 D$ ). On any given day of the study, the LH concentration was the lowest before the GnRHa injection $\left(0.01 \pm 00 \mathrm{ng} \cdot \mathrm{mL}^{-1}\right)$. Following GnRHa injection on the first day of treatment (first physiological stage), LH levels increased to $6.01 \pm 1.8 \mathrm{ng}$ and $11.2 \pm$ $1.8 \mathrm{ng} \cdot \mathrm{mL}^{-1}$ at 1 and $2 \mathrm{~h}$, respectively (time $x$ treatment interaction; $P<0.001$; fig ure 1D). After day 1 (second physiological stage), LH levels increased only slightly (to less than $2 \mathrm{ng} \cdot \mathrm{mL}^{-1}$ ) but significantly higher at $1 \mathrm{~h}$ following treatment, and was higher than at time $0 \mathrm{~h}$ when compared to the saline control group calves (time $\times$ treatment interaction; figure $1 C, D ; P<0.001$ ). The $\mathrm{LH}$ concentration after GnRHa treatment did not change statistically between days 2 and 10 of the study (day $\times$ time interaction; $P>0.10$ ) but was always higher at 1 and $2 \mathrm{~h}$ in GnRHa agonist-treated calves (time $\times$ treatment interaction; $P<0.001$ ). Over the 3 days of superovulatory treatment, LH concentrations at the three sampling times $(0$, 1 and $2 \mathrm{~h}$ ) were statistically different between the saline control and GnRH agonist groups $(P<0.06)$. LH concentrations at the third stage were higher at 1 and $2 \mathrm{~h}$ as compared to $0 \mathrm{~h}$ but only in GnRHa-treated calves (time $\times$ treatment interaction; $P<0.001$ ). 

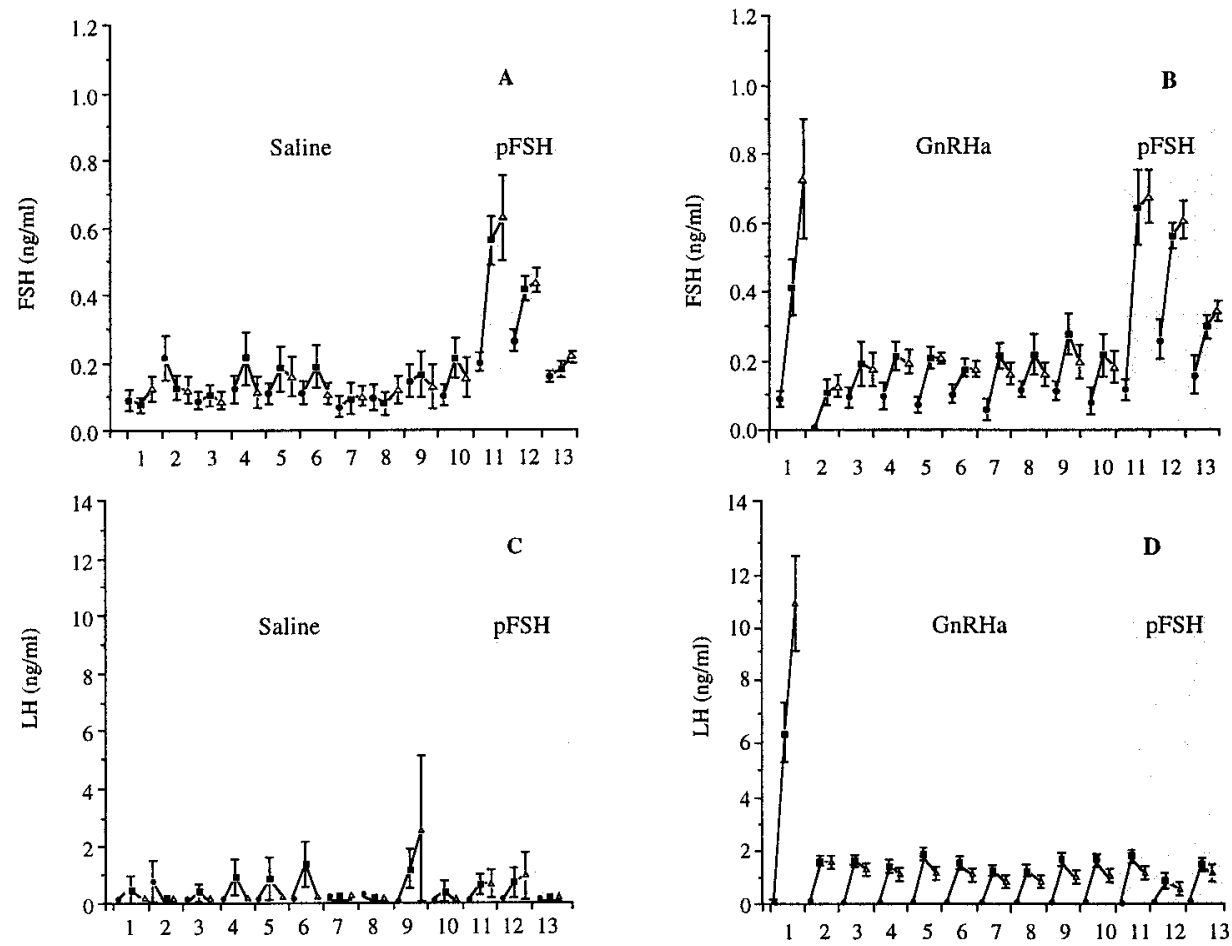

Days of the experiment

Days of the experiment

Figure 1. FSH and LH levels in calves treated with saline (A and $\mathbf{C}$ ) or $\mathrm{GnRH}$ agonist for 13 days $($ B and D) at time $0 \mathrm{~h}(\mathbf{O}), 1 \mathrm{~h}(\boldsymbol{\square})$ and $2 \mathrm{~h}(\triangle)$ following daily treatment. For the last 3 days calves received a superovulatory treatment with $\mathrm{pSFH}$.

Effect: LH: 1, GnRH agonist versus saline control, $P<0.03$, for the 1st physiological stage; 2, hours $(0 \mathrm{~h}$ versus $1 \mathrm{~h}$ versus $2 \mathrm{~h}) \times$ treatment $(\mathrm{GnRH}$ agonist versus saline control); $P<0.005$, for the last two physiological stage. FSH: 1, GnRH agonist versus saline control, $P<0.02$, for the 1 st physiological stage; 2 , hours $(0 \mathrm{~h}$ versus $1 \mathrm{~h}$ versus $2 \mathrm{~h}) \times$ treatment ( $\mathrm{GnRH}$ agonist versus saline control); $P<0.0001$, for the last two physiological stages; 3 , time (d 11 versus $d 12$ versus $d 13$ ) $\times$ hours $(0 \mathrm{~h}$ versus $1 \mathrm{~h}$ versus $2 \mathrm{~h}$ ), $P<0.0001$, for the 3 rd physiological stage.

In control calves (figure $2 A$ ) and those treated with the GnRHa agonist for 13 days (figure $2 B$ ), concentrations of oestradiol$17 \beta$ increased statistically over the 3 days $(P<0.001)$ of the superovulatory treatment and did not differ between saline control and GnRH agonist groups.

\subsection{Macroscopic follicles}

The mean diameters of the largest $(\mathrm{F} 1)$ follicles of calves treated with GnRHa for
13 days were not significantly different from those of the saline control calves. The maximum diameters of the $\mathrm{F} 1$ follicles were 12.3 \pm 0.6 and $10.5 \pm 0.15 \mathrm{~mm}$ in calves treated with saline and with GnRHa for 13 days, respectively (data not shown). The maximum diameter of the $\mathrm{F} 1$ follicle was observed at $8.4 \pm 2.4$ and $2.3 \pm 0.3$ days for control and GnRHa groups, respectively. The mean number of macroscopic follicles observed at these times were $1.5 \pm 0.3$ and $1.4 \pm 0.4$, respectively, for saline and GnRHa groups. 


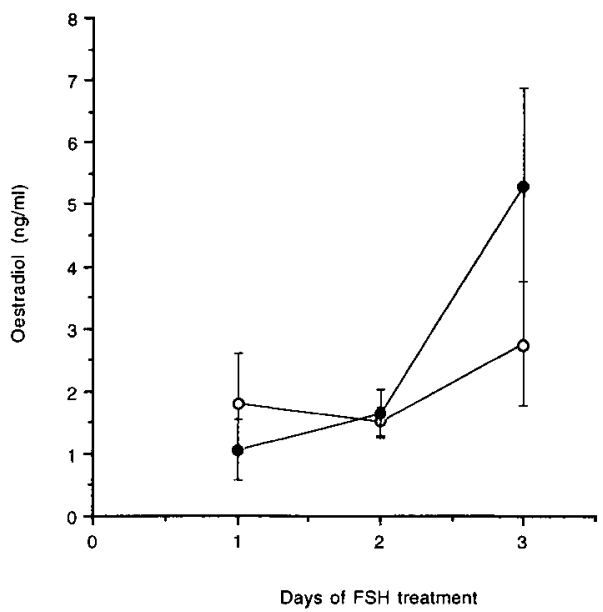

Figure 2. Oestradiol-17 $\beta$ concentrations in calves treated for 3 days with pFSH following a pretreatment with saline control ( $O$ circles) or GnRHa (O circles).

Effect: day (11, 12 and 13); $P<0.001$.

No ovulation was observed throughout the experiment.

\subsection{Overall population of follicles following hormonal treatments}

The mean numbers ( \pm sem) of normal plus atretic antral follicles in the smallest size class were similar for calves treated with saline or GnRHa, being $94.0 \pm 26.9$ and $147.0 \pm 56.5$ in nonsuperovulatory ovaries and $111.8 \pm 36.3$ and $120.8 \pm 60.2$ in superovulatory ovaries, respectively (table I). Before superovulation, the mean number of nonatretic antral follicles in the largest size class was greater in calves previously treated with GnRHa compared with those treated with saline $(2.2 \pm 1.3$ versus $0.6 \pm 0.2$; $P<0.05$ ). However, the mean numbers of atretic follicles of the two largest size classes were similar for calves treated with saline or GnRHa treatments $(5.8 \pm 2.3$ and $1.4 \pm 0.7$ versus $10.4 \pm 4.7$ and $2.4 \pm 1.4$, respectively, for classes 2 and 3 in saline and GnRHatreated calves; $P>0.10$ ). The mean num- bers ( \pm sem) of normal plus atretic antral follicles in the smallest size class were similar for calves treated with saline or GnRHa, at $94.0 \pm 26.9$ and $147.0 \pm 56.5$ in nonsuperovulatory ovaries (table I). Therefore, $\mathrm{GnRH}$ agonist allowed more than a single large follicle to pursue their growth without going to atresia.

The pFSH superovulatory treatment significantly increased the mean number of normal follicles in the medium (3.00-5.4 mm) and large classes (>5.4 mm). Superovulated ovaries in saline control calves had 10.6 medium and 7.8 large normal follicles compared with 4.8 and 0.6 follicles in unstimulated ovaries of the same group $(P<0.05)$. In GnRHa-treated calves, FSH-treated ovaries had 14.6 medium and 11.8 large normal follicles compared with 8.2 and 2.2 for unstimulated ovaries of the same group $(P<0.05)$. In addition, pFSH superovulatory treatment decreased the mean number of atretic follicles in the medium size class (3.00-5.4 mm) in saline control (from 5.8 \pm 2.3 to $2.2 \pm 1.0$ ) and GnRHa agonist groups $(10.4 \pm 4.7$ to $7.0 \pm 3.9 ; P<0.02)$.

When the effect of GnRHa treatment was determined within treated calves by comparing differences between the two ovaries of the same calf, it was observed that in saline control calves, $\mathrm{pFSH}$ significantly increased the number of large $(>5.4 \mathrm{~mm}$ ) nonatretic follicles only, while in GnRHa agonist calves, pFSH also decreased the number of medium size (3.00-5.4 mm) atretic follicles Atresia was similar between the two experimental groups (figure 3 ).

Therefore, the increase in the number of medium and large size follicles observed following FSH stimulation is at least in part due to a decrease in atresia in medium size follicles.

\subsection{Mean diameter and histological condition of the two largest follicles}

In the saline control group, the largest two follicles (F1 and F2) of two calves were 


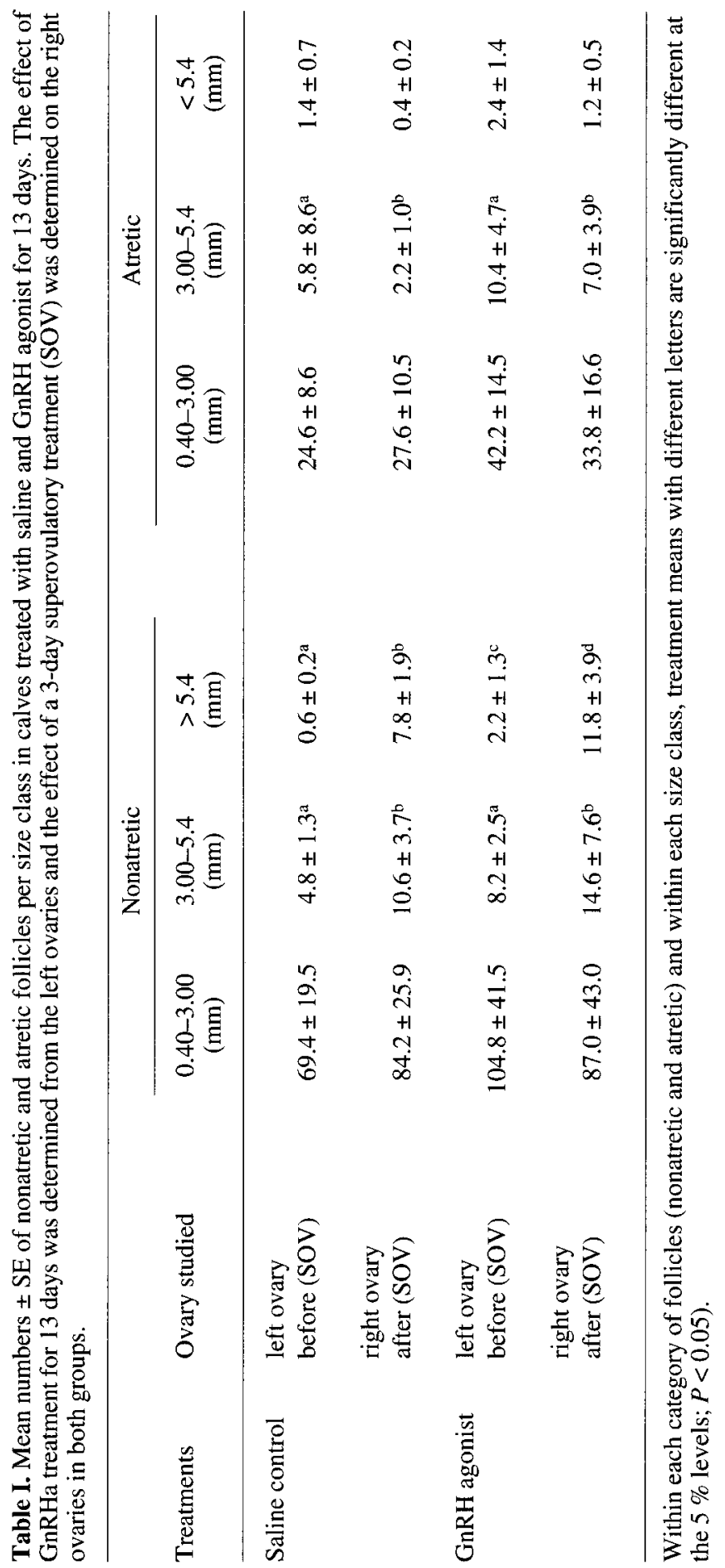




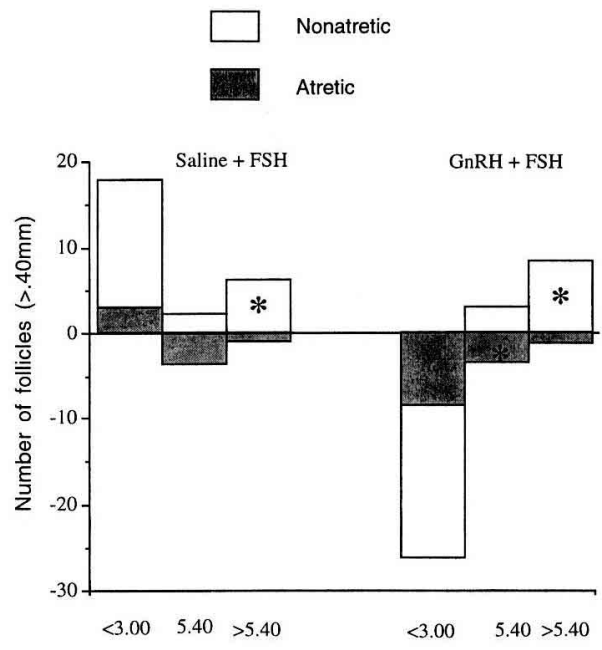

Size (diam.) of follicles $(\mathrm{mm})$

Figure 3. Differences in the mean number of nonatretic and atretic antral follicles between the two ovaries of calves treated with saline and GnRH agonist prior to $\mathrm{pFSH}$ superovulatory treatment. Asterisks within a column indicate differences in number of follicles between calves treated alike $(P<0.05)$.

atretic at the end of the initial treatment (6.1, $4.5 \mathrm{~mm} ; 9.4,3.2 \mathrm{~mm}$, for the $\mathrm{F} 1$ and $\mathrm{F} 2$ of each calf). In the same group, one of the two largest follicles was atretic at the end of the initial treatment for two additional calves $(11.2,8.3 \mathrm{~mm} ; 11.0,10.0 \mathrm{~mm}$, respectively, for the atretic and nonatretic follicle in each calf). Only one calf in this group had no large atretic follicles $(5.5$ and $3.9 \mathrm{~mm})$. Among the five calves treated initially with GnRH agonist for 10 days, the largest two follicles were atretic for two $(12.0,6.9 \mathrm{~mm}$; $5.4,4.8 \mathrm{~mm}$ ), one of the two largest follicles was atretic in two additional calves (8.1, 7.8 , and $7.3,6.4 \mathrm{~mm}$, respectively, for the atretic and nonatretic in each calf), and only one calf had no large atretic follicle (4.0 and $3.7 \mathrm{~mm})$.

Following pure porcine FSH treatment, the Fl follicles of one calf pretreated with saline $(11.3 \mathrm{~mm})$ and two calves pretreated with $\mathrm{GnRHa}(10.8$ and $9.3 \mathrm{~mm}$ ) were atretic, and all F2 follicles were nonatretic. The nonatretic $F 1$ and $F 2$ follicles observed after purified porcine FSH treatment and saline pretreatment had mean diameters of 9.6 and $8.4 \mathrm{~mm}$ (from 8.7 to $10.2 \mathrm{~mm}$ and 6.0 to $10.0 \mathrm{~mm}$ for the $\mathrm{F} 1$ and $\mathrm{F} 2$ follicles, respectively) while those with GnRHa pretreatment had diameters of 10.2 and $9.8 \mathrm{~mm}$ (from 7.7 to $12.4 \mathrm{~mm}$ and 7.6 to $12.3 \mathrm{~mm}$ for the $F 1$ and $F 2$ follicles, respectively).

Therefore the histological conditions of the two largest follicles observed at the end of GnRHa treatment were similar to those observed in saline control calves.

\section{DISCUSSION}

The GnRH agonist treatment was studied as a mean of synchronizing follicular development among calves, and preventing the terminal growth of follicles and appearance of dominant follicles which are normally seen in prepubertal calves. In calves, a daily dose of $48 \mu \mathrm{g}$ of Leuprolide did not impair follicular development as shown using ultrasound, by the presence of a large follicle. At least one large follicle was present in all calves during the time course of the study in the saline control group as well as GnRHatreated calves, and the mean diameter of the large follicles did not change significantly throughout the study. This shows that the normal pattern of follicle recruitment and selection of a dominant follicle, as previously reported in prepubertal calves [2, 13], is maintained in the presence of $\mathrm{GnRHa}$. Bergfeld et al. [3] using 13-month-old prepubertal calves not only confirmed our observations, but observed increased follicular growth and maximum size of the $\mathrm{F} 1$ follicle after a 28-day treatment with GnRHa.

However, it should be noted that almost all dominant follicles were found to be atretic when studied histologically, both in the control group and in calves treated with GnRHa. Therefore, the dominant follicles 
which are observed during the prepubertal period appear to persist as atretic follicles. Whether or not these atretic follicles retain their biological activity is not known but ovulation could not be induced by GnRH injections in calves with large follicles. In postpubertal heifers, induction of ovulation of large follicles has been shown to be dependent on the ovarian status at the time of GnRH injection, especially when the largest follicle was undergoing atresia [27].

In a recent study, Maclellan et al. [19] also used an agonist of GnRH to limit the development of large follicles in order to improve the ovarian response of calves to a superstimulatory treatment with FSH. However, they observed no difference in follicle numbers and growth following a GnRHa treatment imposed for 8 days in 6-month-old calves and during superstimulation when compared to control calves treated with FSH. Whether or not the difference in age of calves in the two studies could explain the discrepancy in ovarian response is not known but it would appear that the duration of agonist treatment is involved. It could be that, as in postpubertal heifers, a longer treatment period was necessary in order to completely inhibit the development of ovarian follicles and that this inhibition would not be observed with a shorter treatment.

Although the GnRHa treatment did not produce differences in the number of follicles larger than $5 \mathrm{~mm}$ in diameter and visible by ultrasound, histological observations showed that the number of the largest size class was increased by $\mathrm{GnRHa}$ treatment. Because the rate of atresia was not influenced by long-term GnRHa treatment, it would appear that the gonadotrophin hormones resulting from such GnRH agonist treatment allowed large size follicles to maintain their integrity and to continue growing but at a slower rate than in saline control calves since the rate of atresia of follicles was not influenced by such a GnRH agonist treatment.
The first GnRH injection in the present study induced a six-fold increase in $\mathrm{LH}$ secretion, similar to that described by Evans [12], Dobson [8] and Bergfeld [3] in prepubertal calves. On the days following, however, the pituitary gland appeared to be partially desensitized; LH release following GnRHa injections was of shorter duration and the level was much lower than that observed on the first day of treatment, as reported in postpubertal heifers [16]. Similarly, Dobson [8] observed a maximum LH release some $4 \mathrm{~h}$ after GnRHa injections on the first day of treatment. Likewise, FSH secretion continued to be secreted at levels higher than in the saline control group. As did the concentration of LH, the concentration of FSH increased by a factor of about six following the first day of GnRHa injection.

While few calves treated with saline showed LH and FSH secretory activities with our bleeding regime, GnRHa injections resulted in secretory activities, as detected by this regime, in all treated calves. In addition, as indicated by the standard errors of the means, it appears that GnRHa synchronized all calves to secrete gonadotropin hormones at a fixed time from GnRHa treatment and at similar levels. In contrast, in saline control calves, there were large standard errors for the means of gonadotropin at each bleeding period, indicating that the pituitary hormones were secreted at random as was demonstrated previously in immature calves. Whether or not the secretory activities of LH and FSH would have been observed outside of the three bleeding times used in this study is not known, but our results are supported by other observations on prepubertal heifers [3] which showed that the maximum levels of hormones were observed $2 \mathrm{~h}$ after GnRHa treatment, thereby supporting our results. Gong et al. [16], using postpubertal heifers, also showed that the maximum levels of LH and FSH were observed within $2 \mathrm{~h}$ following GnRHa injection. 
In saline control calves, peaks of $\mathrm{LH}$ secretion were observed in a very sporadic manner in only a few animals during the time course of the study. The possibility that pulse generators might have been immature in calves with no observed $\mathrm{LH}$ peaks cannot be ruled out because blood sampling was restricted to the early morning. However, as reported by Dobson [7], not all prepubertal calves show pulses of LH early in life.

After GnRHa treatment, purified porcine FSH injections stimulated follicular development. The $F 1$ and $F 2$ follicles of animals so treated reached a maximum of 12 and $10 \mathrm{~mm}$, respectively, within 3 days. Based on the diameter of the two largest nonatretic follicles present at the start of FSH treatment $(3.0 \pm 0.6$ and $2.7 \pm 0.3 \mathrm{~mm}$ for the $\mathrm{F} 1$ and F2 follicles after 11 days of GnRHa treatment) these follicles grew at a rate of around 2.5 and $2.1 \mathrm{~mm}$ per day under purified porcine FSH stimulation. LH secretion observed when GnRHa injections were continued along with FSH stimulation increased the number of nonatretic follicles in the two largest size classes as determined histologically. Indeed, FSH treatment in the presence of GnRHa increased the number of nonatretic follicles in the intermediate and the largest size class by significantly reducing atresia at the end of treatment when comparing the two ovaries of a same calf. The FSH treatment increased the number of follicles in the two largest size classes, suggesting that the passage of follicles from small to large classes is somewhat influenced by FSH, at least above a certain basic level, confirming the observations of Lussier et al. [18].

Ovarian response to FSH appears to be much more dependent on the number of follicles present at treatment than on the presence of large follicles, and the dominance of the F1 follicle, if present in calves, does not appear to block superovulation as was reported for cycling heifers [17].

Significant amounts of oestradiol-17 $\beta$ were secreted in GnRHa and saline control- treated calves in response to pFSH stimulation. The FSH used in the present experiment had very little LH contamination (less than $1 \%$ ). Because no exogenous $\mathrm{LH}$ was supplied in the present experiment and oestradiol-17 $\beta$ secretion was similar in saline control and GnRH agonist-treated calves, it appears that the very low amount of endogenous LH (saline control group) was adequate to stimulate androstenedione synthesis to be used as a substrate for aromatization. It also appears that the LH requirement for growth and estrogenicity of large follicles is not absolute and that FSH can have a similar action. This is not surprising because large estrogenic follicles have FSH receptors [4] and both LH and FSH receptors use the adenylate cyclase system for granulosa cells stimulation [20].

In conclusion, the high between-calf variation in the number of microscopic follicles is independent of the normal F1 development observed by ultrasonography of the ovaries of prepubertal calves. Synchronization of the population of antral follicles is possible but only when FSH and LH secretory activity is maintained by GnRH agonist treatment for 13 days which allows recruited follicles to accumulate in the large size class of follicles in a synchronous fashion. Ovulatory follicles are selected from the reserve pool during superovulatory treatment with purified porcine FSH and develop in a steady synchronous state as shown by the sustained oestradiol- $17 \beta$ secretory activity.

\section{ACKNOWLEDGEMENTS}

The authors wish to thank J.-L. Touzé, A. Thomas, C. Guénette, A. Locatelli, D. André, C. Gauthier, H. Khatir, P. Lonergan, A. Begué, M.-A. Driancourt, C. Dervin and P. Rouillier for their contribution.

\section{REFERENCES}

[1] Adams G.P., Control of ovarian follicular dynamics in cattle: implications for synchronization and superstimulation, Theriogenology 41 (1994) 19-24. 
[2] Adams G.P., Evans A.C.O., Rawlings N.C., Follicular waves and circulating gonadotrophins in 8-month-old prepubertal heifers, J. Reprod. Fertil. 100 (1994) 27-33.

[3] Bergfeld E.G.M., D'Occhio M.J., Kinder J.E., Pituitary function, ovarian follicular growth, and plasma concentrations of $17 \beta$-Estradiol and progesterone in prepubertal heifers during and after treatment with the luteinizing hormonereleasing hormone agonist Deslorelin, Biol. Reprod. 54 (1996) 776-782.

[4] Carson R.S., Findlay J.K., Burger H.G., Trouson A.O., Gonadotropin receptors of the ovine ovarian follicle during follicular growth and atresia, Biol. Reprod. 21 (1979) 75-87.

[5] Cody R.P., Smith J.K., Applied Statistics and the SAS Programming Language, 4th ed., Prentice-Hall Canada, Inc., Toronto, 1997.

[6] Desaulniers D.M., Lussier J.G., Goff A.K., Bousquet D., Guilbault L.A., Follicular development and reproductive endocrinology during a synchronized estrous cycle in heifers and mature cows displaying contrasting superovulatory responses, Domestic Anim. Endocrinol. 12 (1995) 117-131.

[7] Dobson S.E., McLeod B.J., Haresign W., Peters A.R., Lamming G.E., Endocrine changes from birth to puberty in the heifer, J. Reprod. Fertil. 82 (1988) 527-538.

[8] Dobson S.E., McLeod B.J., Lamming G.E., Peters A.R., Ovulatory responses to continuous administration of GnRH in nine-month-old prepubertal beef heifers, Anim. Reprod. Sci. 22 (1990) 271-280.

[9] Driancourt M.A., Follicular dynamics in sheep and cattle, Theriogenology 35 (1991) 55-79.

[10] Dufour J.J., Saumande J., Matton P., Sirard M.-A., Long term effects of a GnRH agonist with or without pFSH on follicular growth regulation in the bovine, Biol. Reprod. 50 (1994) 64 (abstract).

[11] Erickson B.H., Development and senescence of the postnatal bovine ovary, J. Anim. Sci. 25 (1966) 800-805.

[12] Evans A.C.O., Rawlings N.C., Effects of a longacting gonadotrophin-releasing hormone agonist (Leuprolide) on ovarian follicular development in prepubertal heifer calves, Can. J. Anim. 74 (1994) 649-656.

[13] Evans A.O.C., Adams G.P., Rawlings N.C., Follicular and hormonal development in prepubertal heifers from 2 to 36 weeks of age, J. Reprod. Fert. 102 (1994) 463-470.

[14] Fortune J.E., Ovarian follicular growth and development in mammals, Biol. Reprod. 50 (1994) 225-232.

[15] Gong J.G., Bramley T.A., Gutierrez C.G., Peters A.R., Webb R., Effects of chronic treatment with a gonadotrophin-releasing hormone agonist on peripheral concentrations of FSH and
$\mathrm{LH}$, and ovarian function in heifers, J. Reprod. Fertil. 105 (1995) 263-270.

[16] Gong J.G., Campbell B.K., Bramley T.A., Gutierrez C.G., Peters A.R., Webb R., Suppression in the secretion of follicle-stimulating hormone and luteinizing hormone, and ovarian follicle development in heifers continuously infused with a gonadotropin-releasing hormone agonist, Biol. Reprod. 55 (1996) 68-74.

[17] Guilbault L.A., Grasso F., Lussier J.G., Rouillier P., Matton P., Decreased superovulatory responses in heifers superovulated in the presence of a dominant follicle, J. Reprod. Fert. 91 (1991) 81-89.

[18] Lussier J.G., Matton P., Guilbault L.A., Grasso F., Mapletoft R.J., Carruthers T.D., Ovarian follicular development and endocrine responses in follicular-fluid-treated and hemi-ovariectomized heifers, J. Reprod. Fert. 102 (1994) 95-105.

[19] Maclellan L.J., Bergfeld E.G.M., Earl C.R., Fitzpatrick L.A., Aspden W.J., Kinder J.E., Walsh J., Trigg T.E., D'Occhio M.J., Influence of the Luteinizing Hormone-Releasing Hormone Agonist, Deslorelin, on patterns of Estradiol-17 $\beta$ and Luteinizing hormone secretion, ovarian follicular responses to superstimulation with Follicle-Stimulating hormone, and recovery and in vitro development of oocytes in heifer calves, Biol. Reprod. 56 (1997) 878-884.

[20] Mariana J.C., Monniaux D., Driancourt M.A., Mauleon P., Folliculogenesis, in: Cupps E.T. (Ed.), Reproduction in Domestic Animals, Academic Press, San Diago, 1991, pp. 117-171.

[21] Maurasse C., Matton P., Dufour J.J., Ovarian follicular populations at two stages of an estrous cycle in heifers given high energy diets, J. Anim. Sci. 61 (1983) 1194-1200.

[22] McNeilly A.S., Picton H.M., Campbell B.K., Baird D.T., Gonadotrophic control of follicle growth in the ewe, J. Reprod. Fertil. Suppl. 43 (1991) 177-186.

[23] Monniaux D., Chupin D., Saumande J., Superovulatory responses of cattle, Theriogenology 19 (1983) 55-81.

[24] Romero A., Albert J., Brink Z., Seidel G.E. Jr, Numbers of small follicles in ovaries affect superovulation response in cattle, Theriogenology 35 (1991) 265 (abstract).

[25] SAS, SAS/STAT User's Guide (Release 6.04) Cary, NC, Statistical Analysis System Institute, Inc., 1989.

[26] Saumande J., Concentrations of luteinizing hormone, oestradiol-17 $\beta$ and progesterone in plasma of heifers treated to induce superovulation, J. Endocrinol. 84 (1980) 425-437.

[27] Twagiramungu H., Guilbault L.A., Proulx J., Ramkumar R., Dufour J.J., Histological populations and atresia of ovarian follicles in postpartum cattle treated with an agonist of Gonadotropin-Releasing Hormone, J. Anim. Sci. 72 (1994) 192-200. 